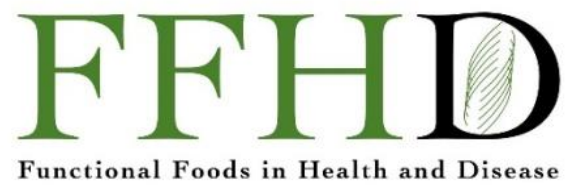

\title{
Chemometric analysis of ketogenic diet formulated from low-cost dietary fibers
}

\section{Omowumi T. Kayode ${ }^{1 *}$, Abolanle A. A. Kayode ${ }^{2}$, Teniola Peace Oyebode ${ }^{3}$}

${ }^{1}$ Biochemistry Unit, Department of Biological Sciences, Mountain Top University, Ogun State, Nigeria; ${ }^{2}$ Department of Biochemistry, School of Basic Medical Sciences, Babcock University, Ogun State 121103, Nigeria; ${ }^{3}$ Department of Biochemistry, Landmark University, Omu Aran, Kwara State 251101, Nigeria.

*Corresponding Author: Omowumi T. Kayode, PhD, Biochemistry Unit, Department of Biological Sciences, Mountain Top University, Ogun State, Nigeria

Submission Date: November $4^{\text {th }}, 2021$; Acceptance Date: December 23 ${ }^{\text {rd }}, 2021$; Publication Date: January $31^{\text {st }}, 2022$

Please cite this article as: Kayode O.T., Kayode A.A.A., Oyebode T.P. Chemometric analysis of ketogenic diet formulated from low-cost dietary fibers. Functional Foods in Health and Disease 2022; 12(1): 46-55. DOI: https://www.doi.org/10.31989/ffhd.v12i1.857

\section{ABSTRACT}

Background: Ketogenic diet (KD) is a beneficial nutritional plan consisting of low carbohydrate, high fat, and moderate protein levels and aids in amelioration of some metabolic disorders. The objective of this study is to develop a ketogenic diet model using cheap and readily available fiber sources.

METHODS: Cabbage head and coconut fruits were obtained and processed into fiber and ketogenic diet chow. They were further analyzed using standard methods for proximate, mineral, and heavy metals, phytochemicals, and DPPH radical scavenging assay.

RESULTS: Carbohydrate content of the samples were $(3.35,4.00,3.16$ and 2.08\%) for cabbage feed, coconut feed, coconut fiber, and cabbage fibers, respectively. This conforms to the maximal $4 \%$ carbohydrate required for ketogenic diet daily allowable limit. Other nutrients such as lipids and proteins were in high and moderate amounts respectively. Phytochemicals were also present in varied proportions in the samples. 
CONCLUSION: The developed cabbage and coconut fiber is an appropriate fiber source for ketogenic diet preparation. They are rich in nutrients based on their mineral content. They may be positioned as a nutraceutical for therapeutic and disease prevention action due to their inherent bioactive chemicals and radical scavenging activity. They may pose negligible toxicity risks as the few detected heavy metals are within permissible limits.

KEYWORDS: Fibers, ketogenic diet, cabbage, coconut, chemical analysis, and antioxidant

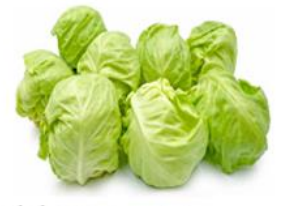

Cabbage

Bulbs

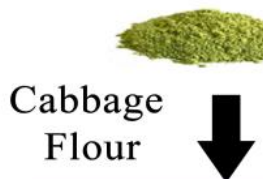

Chemometric

Analysis

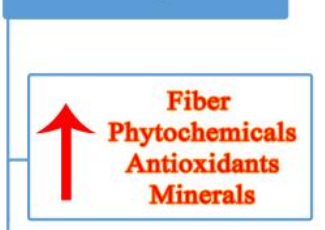

Keto Genic Diet and

Nutraceutical use

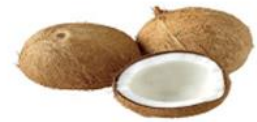

Coconut

Fruit

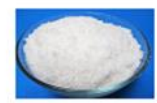

Coconut

Flour

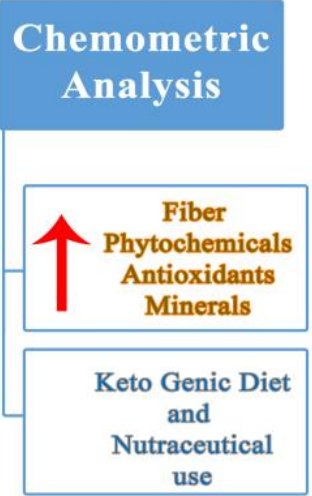

CFFC 2022. This is an Open Access article distributed under the terms of the Creative Commons Attribution 4.0 License (http://creativecommons.org/licenses/by/4.0)

\section{INTRODUCTION}

Ketogenic diet (KD) is a specialized diet that is classically composed of high fat, moderate protein, and low carbohydrate mix, of which the carbohydrate content is as low as four percent [1-3]. It has been adopted for treatment of several metabolic conditions [4]. Consumption of KD is marked by generation of ketone bodies such as acetone, acetoacetate, and betahydroxybutyrate by the hepatic cells and these serves to provide energy to muscle, heart, and brain tissues $[1,5]$. Recent studies have linked KD to the treatment of certain metabolic disorders such as obesity, type II diabetes mellitus, epilepsy, and cancers [6-9]. A few studies had raised concerns over prolonged consumption of KD as it may cause reduced skeletal muscle uptake of glycogen, but this may still serve as a treatment strategy for resistance to increased physical activity [10]. KD may therefore pose no obvious threat to life when ingested for short term but may rather contribute to extension of lifespan and general wellness of consumers.

Despite the several benefits of KD, it is not popular in many African regions due to cost implication of obtaining 
imported low carbohydrate fiber, especially for the preparation of the diet. The aim of this research therefore is to develop nutritious low carbohydrate fibers from cheap and readily available (indigenous) sources.

\section{METHODS}

Fiber preparation: Cabbage heads weighing $2.5 \mathrm{~kg}$ and coconut fruits weighing $1.5 \mathrm{~kg}$ were obtained from Omu Aran Market, Nigeria. The cabbage heads were rinsed in distilled water and diced with sharp knife on a vegetable cutter. The diced portion (100g) was blended in 1 liter of clean water using mechanical laboratory blender. The mixture obtained was poured into a white cotton flannel sieve to separate the water from the fiber. The wet fiber obtained as residue on the sieve was air dried at room temperature for 48 hours and thereafter milled into fine flour using a dry mill. The cabbage flour obtained (750g) was stored in an airtight polythene bag prior to analysis and feed preparation. The coconut fruits were deshelled, and the succulent fruit was cut into small cubes. A portion of $50 \mathrm{~g}$ was blended in $400 \mathrm{~mL}$ of clean water per time until all the whole bulk is done. The fiber was separated from the milk through sieving with cotton flannel and thereafter air dried for twenty-four hours at room temperature prior to milling into fine flour. Total yield was $530 \mathrm{~g}$ of flour which was stored in an airtight polythene bag.

Cabbage and coconut flour were used to compound ketogenic diet feed using the specification in Table 1, according to the method of Kayode et al. [11].

Table 1. Cabbage and coconut fiber feed composition

\begin{tabular}{|c|c|c|c|}
\hline \multicolumn{2}{|c|}{ Cabbage based feed composition } & \multicolumn{2}{|c|}{ Coconut based feed composition } \\
\hline COMPONENT & WEIGHT(g) & COMPONENT & WEIGHT(g) \\
\hline Cabbage fiber & $500 \mathrm{~g}$ & Coconut fiber & $500 \mathrm{~g}$ \\
\hline Protein & $100 \mathrm{~g}$ & Protein & $100 \mathrm{~g}$ \\
\hline Fat & $250 \mathrm{~g}$ & Fat & $250 \mathrm{~g}$ \\
\hline Vitamin/Minerals & $100 \mathrm{~g}$ & Vitamin/Minerals & $100 \mathrm{~g}$ \\
\hline Food Binder & $50 \mathrm{~g}$ & Food Binder & $50 \mathrm{~g}$ \\
\hline TOTAL & $1000 \mathrm{~g}$ & TOTAL & $1000 \mathrm{~g}$ \\
\hline
\end{tabular}

Proximate studies: This was determined by the method described by on dry weight basis [12]. Crude fat was extracted by Soxhlet method with petroleum ether (40$60^{\circ} \mathrm{C}$ ) for 6 hours. Total nitrogen was determined using the micro-Kjeldahl method and converted to crude protein content by multiplying with a factor of 6.25 . Carbohydrate content was determined by percentage difference of the other proximate parameters summed together. The results are expressed as averages of percentage values on dry weight basis.

Mineral element determination: The mineral contents were analyzed after incineration in a muffle furnace and the ash obtained dissolved in $2.0 \mathrm{M} \mathrm{HCl}$ and diluted to $100 \mathrm{~mL}$ with deionized water. The resulting extract was used for the determination of sodium and potassium by Flame Emission Photometry method. Calcium, magnesium, iron, copper, zinc, and manganese by using Atomic Absorption Spectrophotometer (model 400 Perkin Elmer Analyst) and phosphorus by the Vanadomolybdate colorimetric method of Pearson [13] as described by Kayode and Yakubu [14].

Phytochemical analysis: Qualitative and quantitative phytochemicals of the fibers were determined for the presence of alkaloids, saponins, tannins, glycosides, 
flavonoids, phenols, and steroids using standard methods of Harborne [15], as reported by Kayode and Yakubu [14].

Radical scavenging activity: Estimation of the antioxidant activity of the fibers was done following the DPPH radical quenching assay method as reported by Sarker and Oba [16]. The absorbance was taken at wavelengths $517 \mathrm{~nm}$ for DPPH. The antioxidant capacity was measured according to the following equation:

$$
A C(\%)=(A b-A s / A b) \times 100 \text {. }
$$

Where, $A C=$ antioxidant capacity, $A_{b}=$ absorbance of the blank sample $\left[10 \mu \mathrm{L}\right.$ methanol], and $A_{s}=$ absorbance of the test compound. The results were calculated as $\mu \mathrm{g}$ TEAC g-1 DW

Hydrogen peroxide scavenging potential: The method described by Jayaprakah et al [17]. was adopted. Briefly, a solution of hydrogen peroxide $(20 \mathrm{mM})$ was prepared in sodium phosphate buffer $(\mathrm{pH}$ 7.4). Various concentrations of $1 \mathrm{ml}$ of the extracts or ascorbic acid (reference antioxidant) in methanol were added to $2 \mathrm{ml}$ (20 $\mathrm{mM}$ ) of the hydrogen peroxide. The absorbance was measured at $230 \mathrm{~nm}$, after $10 \mathrm{~min}$ against a blank solution that contained extracts in sodium phosphate buffer without hydrogen peroxide.

Hydroxyl radical scavenging activity: The hydroxyl radical scavenging activity was measured according to the method of Halliwell et al. [18] Briefly, the reaction mixture contained $1.0 \mathrm{ml}$ of reagent $(3.0 \mathrm{mM}$

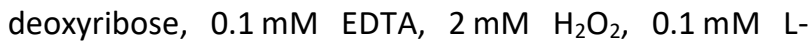
ascorbic acid, $0.1 \mathrm{mM} \mathrm{FeCl} 3.6 \mathrm{H}_{2} \mathrm{O}$ in $10 \mathrm{mM}$ phosphate buffer, $\mathrm{pH}$ 7.4) and various concentrations of the extract $(50-350 \mu \mathrm{g} / \mathrm{ml})$. The reaction mixtures were incubated at $37^{\circ} \mathrm{C}$ for $1 \mathrm{~h}$, and followed by the addition of $1.0 \mathrm{ml}$ of $1 \%$ $(\mathrm{w} / \mathrm{v})$ TBA (in $0.25 \mathrm{M} \mathrm{HCl}$ ) and $1.0 \mathrm{ml} 10 \%(\mathrm{w} / \mathrm{v})$ trichloroacetic acid (TCA). The reaction mixture was adding $1 \mathrm{ml}$ of PMS solution (60 $\mu \mathrm{M}$ ) to the mixture. The reaction mixture was incubated at $25^{\circ} \mathrm{C}$ for 5 minutes, heated in a boiling water bath at $100^{\circ} \mathrm{C}$ for $20 \mathrm{~min}$ and pink chromogen (malondialdehyde-(TBA) adduct) was extracted into $1.0 \mathrm{ml}$ of butan-1-ol and absorbance (Abs) was read at $532 \mathrm{~nm}$ against reagent blank. BHT (butylated hydroxytoluene) served as positive control. The percentage inhibition was calculated using the following expression:

$A_{\text {control }}=$ absorbance of control (containing all reagents except the test compound) and $A_{\text {sample }}=$ absorbance of samples (containing all reagents including the test compound).

Determination of total antioxidant capacity: Total antioxidant capacity was determined according to method described by Prieto et al. [19] Briefly, to $0.1 \mathrm{ml}$ $(0.25 \mathrm{mg} / \mathrm{ml})$ of the extract or standard solutions of ascorbic acid $(20-100 \mu \mathrm{g} / \mathrm{ml})$ was added $1 \mathrm{ml}$ of the reagent solution which consisted of $0.6 \mathrm{M}$ sulphuric acid, $28 \mathrm{mM}$ sodium phosphate and $4 \mathrm{mM}$ ammonium molybdate. The tubes containing the reacting mixture were incubated in a water bath at $95^{\circ} \mathrm{C}$ for $90 \mathrm{~min}$. The mixture was then allowed to stand and cool to room temperature and the absorbance measured at $695 \mathrm{~nm}$ against a blank which consisted of the reacting mixture a distilled water in place of the extract. The antioxidant activities of the extracts were expressed as an ascorbic acid equivalent.

Superoxide radical scavenging activity: The superoxide anion scavenging activity was measured based on the described method [20]. Superoxide radicals were generated in a PMS-NADH system by oxidation of NADH and assayed through reduction of NBT. In this experiment, the superoxide radicals were generated in $3 \mathrm{ml}$ of sodium phosphate buffer (100 mM, pH 7.4) containing $1 \mathrm{ml}$ of NBT $(150 \mu \mathrm{M})$ solution, $1 \mathrm{ml}$ of NADH $(468 \mu \mathrm{M})$ solution, and different concentrations of the CRE $(25-250 \mu \mathrm{g} / \mathrm{ml})$ in water. The reaction started by and the absorbance was measured against the corresponding blank solution. L-Ascorbic acid was used as 
the positive control. The decrease in the extent of NBT reduction, measured by the absorbance of the reaction mixture, correlates with the superoxide radical scavenging activity of the NJE extract. The percentage of superoxide radical scavenging was calculated using the following formula: Superoxide radical scavenging activity $(\%)=\left[\left(A_{0}-A_{1}\right) / A_{0} \times 100\right]$, where $A_{0}$ is the absorbance of the control and $A_{1}$ is the absorbance of NJE or the standard sample.

Statistical analysis: Data was expressed as mean \pm SEM of five replicates. Analysis of Variance complemented with Duncan post hoc was used for the data analysis. IBM SPSS statistics, version 22.0 (SPSS Inc; Chicago USA) was used for the study. Differences were considered statistically significant at $p<0.05$.

\section{RESULTS}

Coconut flour has significantly low levels $(P<0.05)$ of moisture, total protein, fat, and calorific value but significantly higher level $(P<0.05)$ of crude fiber compared to all the other analyzed samples, while cabbage flour has significantly high levels $(P<0.05)$ of moisture and lowest levels of calorific value (Table 2).

The mineral content analysis shown in Table 3 reveals significantly higher level $(P<0.05)$ of sodium in cabbage samples compared to coconut, while all the other minerals were in comparable amount within and between the groups.

Heavy metal analysis data was reported in Table 4. Coconut and cabbage samples revealed significantly low levels $(P<0.05)$ of heavy metals while AS, Pd and I were not detected at all in the coconut samples. Results of the qualitative phytochemical screening are presented in table 5a. Phenolics, glycosides, triterpenes, flavonoids, and alkaloids were detected in the two flour samples while coumarins and steroids were further detected in cabbage flour. Anthocyanins and terpenoids were only present in coconut but not cabbage flours. Furthermore, the quantification of these phytochemicals (Table $5 b$ ) reveals flavonoids has the highest value $(P<0.05)$ amongst all the phytochemicals whilst anthocyanins and glycosides were least.

Table 2. Proximate analysis of cabbage feed, coconut feed, cabbage flour and coconut flour

\begin{tabular}{|l|l|l|l|l|l|l|l|}
\hline & $\begin{array}{l}\text { Moisture } \\
(\%)\end{array}$ & $\begin{array}{l}\text { Ash } \\
(\%)\end{array}$ & $\begin{array}{l}\text { Chow } \\
(\%)\end{array}$ & $\begin{array}{l}\text { Total protein } \\
(\%)\end{array}$ & $\begin{array}{l}\text { Crude fat } \\
(\%)\end{array}$ & $\begin{array}{l}\text { Crude } \\
(\%)\end{array}$ \\
\hline $\begin{array}{l}\text { Cabbage } \\
\text { Feed }\end{array}$ & $5.51 \pm 0.80^{\mathrm{a}}$ & $8.50 \pm 0.63^{\mathrm{a}}$ & $3.35 \pm 0.00^{\mathrm{b}}$ & $17.28 \pm 0.06^{\mathrm{d}}$ & $38.81 \pm 0.02^{\mathrm{c}}$ & $26.55 \pm 0.20^{\mathrm{a}}$ & $1806.85 \pm 0.19^{\mathrm{c}}$ \\
\hline $\begin{array}{l}\text { Coconut } \\
\text { Feed }\end{array}$ & $5.17 \pm 0.12^{\mathrm{a}}$ & $3.16 \pm 0.13^{\mathrm{a}}$ & $4.00 \pm 0.08^{\mathrm{b}}$ & $13.28 \pm 0.23^{\mathrm{c}}$ & $49.25 \pm 0.36^{\mathrm{d}}$ & $25.15 \pm 0.20^{\mathrm{a}}$ & $2143.60 \pm 8.36^{\mathrm{d}}$ \\
\hline $\begin{array}{l}\text { Coconut } \\
\text { Flour }\end{array}$ & $3.66 \pm 0.20^{\mathrm{a}}$ & $0.61 \pm 0.24^{\mathrm{a}}$ & $3.16 \pm 0.37^{\mathrm{ab}}$ & $2.02 \pm 0.13^{\mathrm{a}}$ & $24.71 \pm 0.38^{\mathrm{b}}$ & $65.84 \pm 0.83^{\mathrm{b}}$ & $1017.15 \pm 22.54^{\mathrm{b}}$ \\
\hline $\begin{array}{l}\text { Cabbage } \\
\text { Flour }\end{array}$ & $11.48 \pm 0.00^{\mathrm{b}}$ & $9.27 \pm 3.33^{\mathrm{a}}$ & $2.08 \pm 0.02^{\mathrm{a}}$ & $7.40 \pm 0.02^{\mathrm{b}}$ & $8.77 \pm 0.65^{\mathrm{a}}$ & $61.00 \pm 3.98^{\mathrm{b}}$ & $488.87 \pm 24.45^{\mathrm{a}}$ \\
\hline
\end{tabular}

Results were expressed as Mean \pm SEM 
Table 3. Mineral content of coconut feed, cabbage feed, coconut flour and cabbage flour

\begin{tabular}{|l|l|l|l|l|l|l|l|l|}
\hline \begin{tabular}{l} 
Sample \\
\hline
\end{tabular} $\mathbf{M n}(\mathrm{mg} / \mathrm{kg})$ & \multicolumn{2}{|c|}{$\mathrm{Ca}(\mathrm{mg} / \mathrm{kg})$} & $\mathrm{K}(\mathrm{mg} / \mathrm{kg})$ & $\mathrm{Cl}(\mathrm{mg} / \mathrm{kg})$ & $\mathrm{P}(\mathrm{mg} / \mathrm{kg})$ & $\mathrm{Mg}(\mathrm{mg} / \mathrm{kg})$ & $\mathrm{Na}(\mathrm{mg} / \mathrm{kg})$ & $\mathrm{Fe}(\mathrm{mg} / \mathrm{kg})$ \\
\hline $\begin{array}{l}\text { Coconut } \\
\text { Feed }\end{array}$ & $0.042 \pm 0.02^{\mathrm{a}}$ & $15.042 \pm 0.01^{\mathrm{a}}$ & $2.880 \pm 0.12^{\mathrm{a}}$ & $1.340 \pm 0.02^{\mathrm{a}}$ & $1.315 \pm 0.01^{\mathrm{a}}$ & $0.27 \pm 0.02^{\mathrm{a}}$ & $13.636 \pm 3.02^{\mathrm{a}}$ & $0.096 \pm 0.00^{\mathrm{a}}$ \\
\hline $\begin{array}{l}\text { Cabbage } \\
\text { Feed }\end{array}$ & $0.019 \pm 0.00^{\mathrm{b}}$ & $13.664 \pm 2.02^{\mathrm{a}}$ & $2.995 \pm 0.11^{\mathrm{a}}$ & $1.213 \pm 0.42^{\mathrm{a}}$ & $0.385 \pm 0.02^{\mathrm{b}}$ & $1.031 \pm 0.02^{\mathrm{b}}$ & $40.000 \pm 2.02^{\mathrm{b}}$ & $0.045 \pm 0.01^{\mathrm{b}}$ \\
\hline $\begin{array}{l}\text { Coconut } \\
\text { Flour }\end{array}$ & $0.040 \pm 0.02^{\mathrm{a}}$ & $15.603 \pm 3.01^{\mathrm{a}}$ & $2.865 \pm 0.01^{\mathrm{a}}$ & $1.165 \pm 0.11^{\mathrm{ab}}$ & $1.450 \pm 0.21^{\mathrm{a}}$ & $0.145 \pm 0.12^{\mathrm{a}}$ & $7.727 \pm 0.12^{\mathrm{c}}$ & $0.090 \pm 0.02^{\mathrm{a}}$ \\
\hline $\begin{array}{l}\text { Cabbage } \\
\text { Flour }\end{array}$ & $0.033^{\mathrm{a}} \pm 0.02$ & $13.080 \pm 4.02^{\mathrm{a}}$ & $2.935 \pm 1.00^{\mathrm{a}}$ & $1.043 \pm 0.01^{\mathrm{b}}$ & $0.010 \pm 0.00 \mathrm{c}^{\mathrm{c}}$ & $1.772 \pm 0.03^{\mathrm{ab}}$ & $39.091 \pm 3.02^{\mathrm{b}}$ & $0.075 \pm 0.01^{\mathrm{ab}}$ \\
\hline
\end{tabular}

Table 4. Heavy metals content of coconut feed, cabbage feed, coconut flour and cabbage flour

\begin{tabular}{|c|c|c|c|c|c|c|c|}
\hline Sample & $\mathrm{Cu}(\mathrm{mg} / \mathrm{kg})$ & I (mg/kg) & Se (mg/kg) & $\mathrm{Cd}(\mathrm{mg} / \mathrm{kg})$ & $\mathrm{Pb}(\mathrm{mg} / \mathrm{kg})$ & $\begin{array}{l}\text { As } \\
\text { (ms }\end{array}$ & $\mathrm{Cr}(\mathrm{mg} / \mathrm{kg})$ \\
\hline $\begin{array}{l}\text { Coconut } \\
\text { Feed }\end{array}$ & $0.581 \pm 0.02^{a}$ & Nil & $1.531 \pm 0.01^{a}$ & $0.750 \pm 0.02^{a}$ & Nil & Nil & $0.442 \pm 0.00^{\circ}$ \\
\hline $\begin{array}{l}\text { Cabbage } \\
\text { Feed }\end{array}$ & $0.004 \pm 0.01^{b}$ & $0.599 \pm 0.02^{\mathrm{a}}$ & $1.480 \pm 0.11^{\mathrm{a}}$ & $0.777 \pm 0.01^{\mathrm{a}}$ & $0.072 \pm 0.02^{a}$ & Nil & $0.150 \pm 0.00^{b}$ \\
\hline $\begin{array}{l}\text { Cabbage } \\
\text { Flour }\end{array}$ & $0.003 \pm 0.00^{b}$ & $0.587 \pm 0.02^{a}$ & $1.412 \pm 0.02^{b}$ & $0.410 \pm 0.02^{b}$ & $0.123 \pm 0.01^{b}$ & Nil & $0.435 \pm 0.02^{a}$ \\
\hline
\end{tabular}

Results were expressed as Mean \pm SEM

Table 5a. Qualitative phytochemical screening of coconut flour and cabbage flour

\begin{tabular}{|l|l|l|}
\hline PHYTOCHEMICALS & \multicolumn{1}{|c|}{ COCONUT } & - \\
\hline *Saponin & - & - \\
\hline Tannins & - & + \\
\hline Phenolics & + & - \\
\hline Phlobatanin & - & + \\
\hline Steroids & - & + \\
\hline Flavonoids & + & - \\
\hline Anthrocyanin & + & - \\
\hline Terpenoids & + & + \\
\hline Glycosides & + & + \\
\hline Triterpenes & + & + \\
\hline Alkaloids & + & + \\
\hline Coumarin & - & + \\
\hline
\end{tabular}


Table 5b. Quantitative phytochemical screening of coconut flour and cabbage flour

\begin{tabular}{|l|l|l|}
\hline PHYTOCHEMICALS & COCONUT & CABBAGE \\
\hline Phenolics $\mathbf{m g} / \mathbf{1 0 0 g}$ & $49.63 \pm 0.11$ & $5.69 \pm 0.13$ \\
\hline Flavonoids $\mathbf{m g} / \mathbf{1 0 0 g}$ & $116.07 \pm 4.24$ & $167.10 \pm 1.15$ \\
\hline Anthocyanin $\mu \mathrm{g} / \mathbf{1 0 0 g}$ & $0.33 \pm 0.02$ & $\mathrm{Nil}$ \\
\hline Terpenoids $\mu \mathrm{g} / \mathbf{1 0 0 g}$ & $27.23 \pm 1.06$ & $\mathrm{Nil}$ \\
\hline Glycosides $\mu \mathrm{g} / \mathbf{1 0 0 g}$ & $7.88 \pm 0.32$ & $5.21 \pm 0.24$ \\
\hline Triterpenes $\mu \mathrm{g} / \mathbf{1 0 0 g}$ & $255.18 \pm 3.33$ & $215.85 \pm 0.10$ \\
\hline Alkaloids $\mu \mathrm{g} / \mathbf{1 0 0 g}$ & $43.14 \pm 0.10$ & $34.21 \pm 0.12$ \\
\hline Steroids $\mu \mathrm{g} / \mathbf{1 0 0 g}$ & $\mathrm{Nil}$ & $361.52 \pm 33.00$ \\
\hline Coumarins $\mu \mathrm{g} / \mathbf{1 0 0 g}$ & $\mathrm{Nil}$ & $51.93 \pm 1.94$ \\
\hline
\end{tabular}

Results are expressed in Mean \pm SEM

The DPPH radical scavenging activity of the flours are presented in Table 6 and Figure 1. Inhibition of DPPH by cabbage fiber is significantly higher $(P<0.05)$ at 20,40 , 60,80 and $10 \mathrm{mg} / \mathrm{ml}$ compared to that of coconut flour at the same concentrations. Superoxide scavenging activity presented in table 7 reveals significantly higher $(P<0.05)$ superoxide scavenging activity by coconut flour compared to cabbage fiber at same concentration.

Table 6. DPPH radical scavenging activity of the cabbage and coconut flour

\begin{tabular}{|llllll|}
\hline DPPH & $\begin{array}{l}\text { \% inhibition } \\
\text { @20mg/ml }\end{array}$ & $\begin{array}{l}\text { \% inhibition } \\
@ 40 \mathrm{mg} / \mathrm{ml}\end{array}$ & $\begin{array}{l}\text { \% inhibition } \\
@ 60 \mathrm{mg} / \mathrm{ml}\end{array}$ & $\begin{array}{l}\text { \% inhibition } \\
\text { @80mg/ml }\end{array}$ & $\begin{array}{l}\text { \% inhibition } \\
@ 100 \mathrm{mg} / \mathrm{ml}\end{array}$ \\
\hline COCONUT FLOUR & $8.37 \pm 0.03$ & $9.23 \pm 0.01$ & $26.88 \pm 0.15$ & $37.87 \pm 0.18$ & $47.72 \pm 0.03$ \\
\hline CABBAGE FLOUR & $87.96 \pm 0.75$ & $87.86 \pm 0.12$ & $88.70 \pm 0.18$ & $87.96 \pm 0.09$ & $87.60 \pm 0.03$ \\
\hline ASCORBIC ACID & $89.12 \pm 1.01$ & $90.21 \pm 0.00$ & $91.00 \pm 2.21$ & $91.13 \pm 1.02$ & $93.02 \pm 1.02$ \\
\hline
\end{tabular}

Results are expressed in Mean \pm SEM

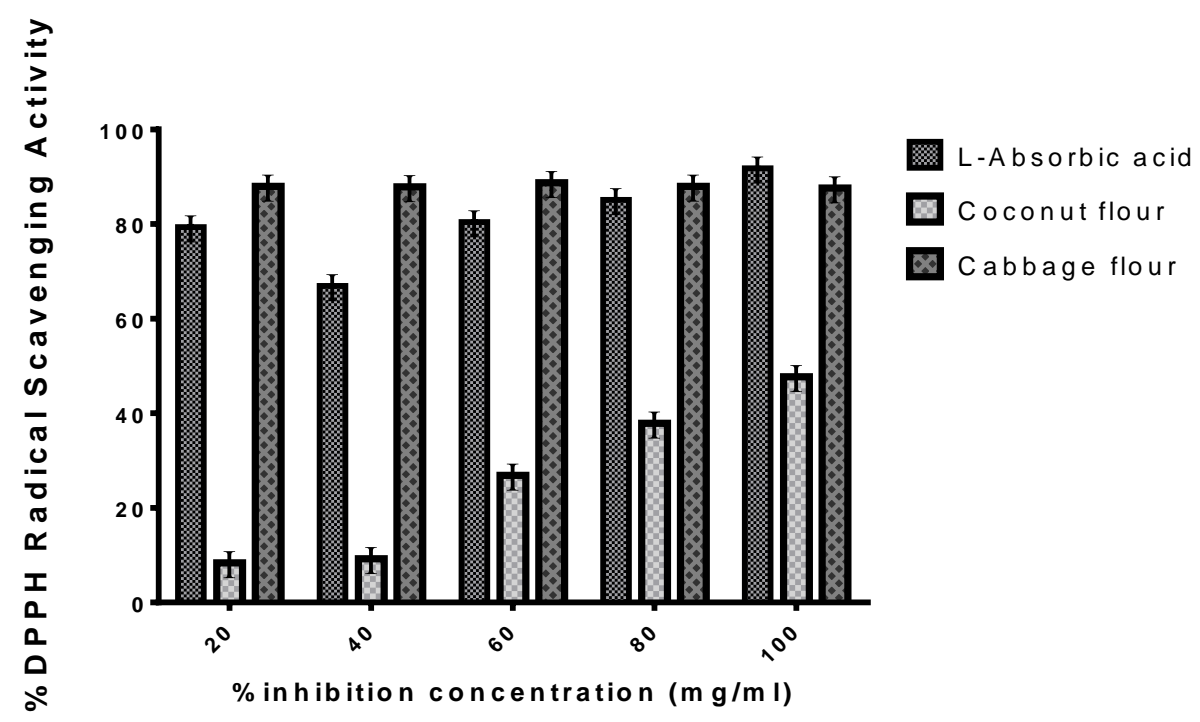

Figure 1. \%DPPH Radical scavenging activity of L-Ascorbic acid, coconut flour and cabbage flour. Results are expressed in Mean \pm SEM $(P<0.05)$ 
Table 7. Superoxide, Hydroxyl, Hydrogen Peroxide Scavenging and Total Antioxidant Capacity Carried Out On Coconut Flour And Cabbage Flour

\begin{tabular}{|c|c|c|c|c|}
\hline SUPEROXIDE & $\begin{array}{l}\text { OH radical scavenging } \\
\text { activity @100mg/ml }\end{array}$ & $\mathrm{H}_{2} \mathrm{O}_{2} @ 50 \mathrm{mg} / \mathrm{dl}$ & TAC @50mg/dl & $\begin{array}{l}\mathrm{O}_{2} \cdot \text { scavenging activity } \\
@ 100 \mathrm{mg} / \mathrm{ml}\end{array}$ \\
\hline COCONUT FLOUR & $205.17 \pm 1.12$ & $10.61 \pm 0.02$ & $804.48 \pm 0.00$ & $2.38 \pm 0.28$ \\
\hline CABBAGE FLOUR & $25.52 \pm 0.63$ & $7.65 \pm 0.03$ & $641.96 \pm 1.96$ & $5.03 \pm 0.28$ \\
\hline ASCORBIC ACID & $30.28 \pm 2.15$ & $24.75 \pm 1.57$ & $970.21 \pm 2.73$ & $28.30 \pm 2.31$ \\
\hline
\end{tabular}

Results are expressed in Mean \pm SEM

\section{DISCUSSION}

Proximate analysis: The high fiber content obtained in the two samples may be important in preparing a low carbohydrate diet for populations that cannot afford refined and imported fibers with an assurance of reduced cost and yet with optimum quality. In our previous work, we reported the use of the coconut and cabbage fibers in compounding feed for laboratory animals for the management of metabolic disorders with success $[2,21]$. The protein content of the feeds may enhance overall protein availability when ingested. This may enhance vital body functions such as growth, maintenance of fluid balance, formation of hormones, enzymes, and sustenance of strong immune function [22]. The moisture content in the cabbage flour, however, indicates it is more prone to deterioration by microorganisms and hence reduction in shelf life compared to the coconutbased fiber [23].

Mineral analysis: Minerals are essential for the regular maintenance of human health when consumed in adequate proportions of recommended dietary allowances (RDA). The presence of myriads of minerals in the developed fibers makes it an interesting sample for dietary inclusion for various feed formulations in nutritional studies and especially the ketogenic diet [24]. The significant elevation of sodium in the cabbage samples, however, may alter electrolyte balance and, as such, may require moderation in consumption especially for individuals with heart-related health issues [25]. The heavy metals content measured in the samples were within permissible limits and may not predispose consumers to any related toxicity.

Phytochemicals: Phytochemicals in plants possess medicinal benefits which includes antioxidant, antipyretic, and anti-inflammatory activities amongst others [26]. They therefore support protection against and treatment of several diseases such as cancer, inflammation, obesity, diabetes, and other metabolic disorders [27]. The presence of diverse phytochemicals in the fibers (especially flavonoids) makes it of interest to nutraceutical and pharmafoods researcher's community as candidates for further investigations.

Antioxidant: Plant flavonoids and steroids have exhibited affinity for hydroxyl, peroxide and superoxide radicals and help in improving health. The cabbage flour acts as better and excellent radical scavenger compared to the coconut flour. The total antioxidant activity of the fibers may be due to their redox properties, which allow them to act as reducing agents, hydrogen donators, and singlet oxygen quenchers since phytochemicals like flavonoids and tannins were able to discolor DPPH solution by their hydrogen donating ability [28-29]. This inherent antioxidant ability of the fibers when ingested will help combat several health conditions whose occurrence and progression had been linked to the generation of free radicals in the biological system [30].

\section{CONCLUSION}

The fibers developed in this study are suitable for use in ketogenic diet formulation as evidenced by the rich 
mineral and required proximate analysis content. They could be positioned as a nutraceutical for therapeutic action due to their inherent phytochemicals and radical scavenging activity. The heavy metals detected were also within permissible limits hence qualifying the fibers as not only nutritious but safe for dietary inclusions.

List of abbreviations: KD: Ketogenic diet, DPPH: 1,1diphenyl-2-picrylhydrazyl, ABTS: 2,2'-azino-bis(3ethylbenzothiazoline-6-sulfonic acid), TEAC: Trolox equivalent antioxidant capacity, IBM: International Business Machines Corporation, SPSS: Statistical Package for the Social Sciences, RDA: Recommended Dietary Allowances

Conflict of Interest: The authors declare there are no conflicts of interest.

Acknowledgement: Authors wish to thank the management of Mountain Top University for the sponsorship of the APC of this manuscript.

Authors Contributions: K-O.T. conceptualization, supervision, and design of experiment. K-O.T and O-T.P. conducted the research. K-O.T., O-T.P and K-A.A.A. analyzed the data. O-T.P., K-O.T and K-A.A.A. Writing Original Draft Preparation. K-O.T,K-A.A.A and O-T.P. Writing - Review \& Editing. O-T.P, K-O.T and K-A.A.A provided essential reagents and materials. All authors read and approved the final manuscript.

\section{REFERENCES}

1. Evans M, Cogan KE, Egan B: Metabolism of ketone bodies during exercise and training: physiological basis for exogenous supplementation. The J.Physiol 2017; 595(9), 2857-2871. https://doi.org/10.1113/ip273185

2. Kayode OT, Adetomiwa VO, Kayode AA: Biochemical and histomorphological changes in testosterone propionate induced benign prostatic hyperplasia in male wistar rats treated with ketogenic diet. Biomed and Pharmacother. 2020a 132:110863

\section{https://doi.org/10.1016/j.biopha.2020.110863}

3. Martin-McGill KJ, Bresnahan R, Levy RG, Cooper PN. Ketogenic diets for drug-resistant epilepsy. Cochr. Datab Sys Rev 2020, 6:CD001903.

https://doi.org/10.1002/14651858.CD001903.pub5

4. Bueno NB, De Melo IS, De Oliveira SL, Da Rocha AT: Verylow-carbohydrate ketogenic diet v. low-fat diet for longterm weight loss: a meta-analysis of randomised controlled trials. British J Nutri 2013; 110(7) 1178-1187. https://doi.org/10.1017/s0007114513000548

5. Kayode OT, Rotimi ER, AfolayanOA,Kayode AA: Ketogenic diet: A nutritional remedy for some metabolic disorders. J Edu Health Sport. 2020b; 10(8).

http://dx.doi.org/10.12775/JEHS.2020.10.08.021

6. Goday A, Bellido D, Sajoux I, Crujeiras AB, Burguera B, García-Luna PP,Casanueva FF: Short-term safety, tolerability and efficacy of a very low-calorie-ketogenic diet interventional weight loss program versus hypocaloric diet in patients with type 2 diabetes mellitus. Nutri Diabet 2016; 6(9), e230.

https://doi.org/10.1038/nutd.2016.36

7. Youngson NA, Morris MJ, Ballard JWO: The mechanisms mediating the antiepileptic effects of the ketogenic diet, and potential opportunities for improvement with metabolism-altering drugs. Seizure 2017; 52, 15-19. https://doi.org/10.1016/j.seizure.2017.09.005

8. Sainsbury E, Kizirian NV, Partridge SR., Gill T, Colagiuri S, Gibson AA: Effect of dietary carbohydrate restriction on glycemic control in adults with diabetes: A systematic review and meta-analysis, Diab Res ClinPrac2018; 139: 239-252.https://doi.org/10.1016/j.diabres.2018.02.026

9. Oliveira CL, Mattingly S, Schirrmacher R, Sawyer MB, Fine EJ, Prado CM: A nutritional perspective of ketogenic diet in Cancer: a narrative review. J AcadNutr Diet 2018. 118:668-688.

https://doi.org/10.1016/j.jand.2017.02.003

10. Chang CK, Borer K, Lin PJ: Low-carbohydrate-high-fat diet: Can it help exercise performance? J Human Kin, 2017. 56(1), 81-92. https://doi.org/10.1515/hukin-2017-0025

11. Kayode O, Rotimi D, Olaolu T, Adeyemi O: Ketogenic diet improves and restores redox status and biochemical indices in monosodium glutamate-induced rat testicular toxicity. Biomed and Pharmacother 2020; 127: 110227 https://doi.org/10.1016/j.biopha.2020.110227 
12. AOAC. Official Methods of Analysis. 18th Edition, Association of Official Analytical Chemists, Gaithersburgs, MD; 2005

13. Pearson D: The Chemical Analysis of Foods. 7th Edn, Churchill Livingstone, London; 1976

14. Kayode OT, Yakubu MT: Parquetinanigrescens leaves: chemical profile and influence on the physical and biochemical indices of sexual activity of male Wistar rats. J Integr Med 2017; 15(1): 64-76. https://doi.org/10.1016/s2095-4964(17)60318-2

15. Harbone JB: Phytochemical Methods-A Guide to Modern Techniques of Plant Analysis. 3rd Edn, Chapman and Hall, London; 1998: 36-89.

16. Sarker U, Oba S: Polyphenol and flavonoid profiles and radical scavenging activity in leafy vegetable Amaranthus gangeticus. BMC Plant Biol2020; 20:499. https://doi.org/10.1186/s12870-020-02700-0

17. Jayaprakasha GK, Singh R, Sakariah K.K: Antioxidant activity of grape seed (Vitis vinifera) extracts on peroxidation models in vitro. Food Chem 2001; 73(3): 285-290.

http://dx.doi.org/10.1016/S0308-8146(00)00298-3

18. Halliwell B, Gutteridge JM, Aruoma OI: The deoxyribose method: a simple "test-tube" assay for determination of rate constants for reactions of hydroxyl radicals. Anal. Biochem 1987; 165(1): 215-219. https://doi.org/10.1016/0003-2697(87)90222-3

19. Prieto $P$, Pineda $M$, Aguilar $M$ : Spectrophotometric quantitation of antioxidant capacity through the formation of a phosphomolybdenum complex: specific application to the determination of vitamin E. Anal. Biochem 1999; 269(2): 337-341.

https://doi.org/10.1006/abio.1999.4019

20. Benzie IF, Strain J.J: Ferric reducing/antioxidant power assay: direct measure of total antioxidant activity of biological fluids and modified version for simultaneous measurement of total antioxidant power and ascorbic acid concentration. Meth. Enzymol 1999; 299:15-27. https://doi.org/10.1016/s0076-6879(99)99005-5

21. Kayode O, Kayode AA, Mgbojikwel, Rotimi D: Effect of Ketogenic Diet on Monosodium Glutamate-Induced Uterine Fibroids in Female Wistar Rats. J Babol Univ Med Sci 2021; 23: 1-8. http://jbums.org/article-1-9224en.html
22. Emebu PK, Anyika JU: Proximate and mineral composition of kale (Brassica oleracea) grown in Delta State, Nigeria. Pak JNutr 2011; 10(2):190-194.

https://dx.doi.org/10.3923/pjn.2011.190.194

23. Fennema RO, Tannenbaum SR: Introduction to Food Chemistry. (Eds.)Marcel Dekker Inc., New York; 1996: 164.

24. Thomas RA, Krishnakumari S: Proximate analysis and mineral composition of Myristica fragrans seeds. J PharmacogPhytochem 2015, 3(6). http://www.phytojournal.com/archives/2015/vol3issu e6/PartA/3-6-20.1.pdf

25. Robert KM, Daryl KG, Peter AM, Victor WR. Harper's Illustrated Biochemistry. In Benders and Mayes Vitamins and Minerals, Lange Medical Books/McGraw-Hill, Medical Publishing Division, New York; 2003: 496.

26. Saxena M, Saxena J, Pradhan A: Flavonoids and phenolic acids as antioxidants in plants and human health. Int. J. Pharm. Sci. Rev. Res, 2012; 16(2):130-134. https://www.globalresearchonline.net/journalcontents /v16-2/28.pdf

27. OnyekaEU,Nwambekwe IO: Phytochemical profile of some green leafy vegetables in South East, Nigeria. Nig Food J 2007; 25(1): 67-76.

https://doi.org/10.4314/nifoj.v25i1.33655

28. Barile E, Bonanomi G, Antignani V, Zolfaghari B, Sajjadi E, Scala F, Lanzotti V: Saponins from Allium minutiflorum with antifungal activity. Phytochem 2007, 68:593-603. https://doi.org/10.1016/j.phytochem.2006.10.009

29. Akharaiyi FC: Antibacterial, phytochemical and antioxidantactivities of Datura metel. Int J Pharmacol Tech Res 2011; 3(1):478-483.

https://sphinxsai.com/Vol.3No.1/pharm janmar11/pdf/JM11(PT=79)\%20pp\%20478-483.pdf

30. Varahalarao V, Kaladhar DS: Antimicrobial study of plant extracts of Datura matel L against some important disease-causing pathogen. Asia Pac J Trop Dis 2012; 2:94-97. https://doi.org/10.1016/S22221808(12)601303 